\title{
Sosialisasi Kinesiologi Olahraga Pada Pembelajaran PJOK Anak Sekolah Dasar
}

\author{
Heni Yuli Handayani ${ }^{1}$ \\ ${ }^{1}$ STKIP PGRI Bangkalan \\ E-mail: heni@stkippgri-bkl.ac.id \\ Septyaningrum Putri Purwoto ${ }^{2}$ \\ ${ }^{2}$ STKIP PGRI Bangkalan \\ E-mail: septyaningrum@stkippgri-bkl.ac.id
}

\author{
Haryo Mukti Wibowo \\ ${ }^{3}$ STKIP PGRI Bangkalan \\ E-mail: haryo@skippgri-bkl.ac.id \\ Fajar Hamdhan Utama ${ }^{4}$ \\ ${ }^{4}$ STKIP PGRI Bangkalan \\ E-mail: fajarhamdhan@stkippgri-bkl.ac.id
}

\section{Article History: \\ Received: 2021-11-03 \\ Revised: 2021-12-17 \\ Accepted:2022-01-13}

Keywords : Sport kinesilogy, Physical education, sports and health, Elementary school students.

\begin{abstract}
Kinesiology is the study of movement. Sports kinesiology is very important for elementary school children and requires teacher assistance in the scope of education. Movement science in learning at school is given in physical education lessons, sports, and health (Penjasorkes). The kinesiology learning model is generally chosen by physical education teachers, not least at the elementary school level. This dedication to socializing sports kinesiology in PJOK learning was successful. This is because it makes students understand more about sports kinesiology in PJOK learning for elementary school children. Through this socialization activity, Movement learning in PJOK must pay attention to the characteristics of elementary school children. In addition, this socialization makes students understand efficient movement, effective movement and avoid injury in PJOK learning.
\end{abstract}

Riwayat Artikel :

Diajukan: 13-11-2021

Diperbaiki: 17-12-2021

Diterima: 13-01-2022
Abstrak: Kinesiologi adalah studi tentang
gerakan. Kinesiologi olahraga menjadi hal
yang sangat penting untuk anak sekolah
dasar dan memerlukan pendampingan guru
dalam lingkup pendidikan. Ilmu gerak dalam 
pembelajaran di sekolah diberikan pada pelajaran pendidikan jasmani olahraga, dan kesehatan (Penjasorkes). Model pembelajaran kinesiologi pada umumnya dipilih oleh guru-guru penjas, tidak terkecuali pada tingkat sekolah dasar. Pengabdian tentang sosialisasi kinesiologi olahraga dalam pembelajaran PJOK ini berhasil. Hal ini dikarenakan membuat siswa lebih paham tentang kinesiologi olahraga dalam pembelajaran PJOK untuk anak sekolah dasar. Melalui kegiatan sosialisasi ini maka. Pembelajaran gerak dalam PJOK harus memperhatikan karakteristik anak sekolah dasar. Selain itu, sosialisasi ini membuat

Kata kunci : Kinesiologi Olehraga, pendidikan jasmani olahraga dan kesehatan, Sekolah dasar siswa memahami gerak yang efisien, gerak yang efektif dan terhindar dari cidera dalam pembelajaran PJOK.

\section{Pendahuluan}

Dalam kurikulum Pendidikan Jasmani di Sekolah Dasar 2004 disebutkan bahwa, Pendidikan Jasmani merupakan proses pendidikan yang memanfaatkan aktivitas jasmani dan direncanakan secara sistematik bertujuan untuk meningkatkan individu secara organik, neuromuskuler, perseptual, kognitif, sosial dan emosional. Lebih jauh ditegaskan bahwa, Pendidikan Jasmani merupakan bagian integral dari sistem pendidikan secara keseluruhan, yang memfokuskan pengembangan aspek kebugaran jasmani, keterampilan gerak, keterampilan berfikir kritis, stabilitas emosional, keterampilan sosial, penalaran dan tindakan moral melalui aktivitas jasmani. Pendidikan Jasmani merupakan media untuk mendorong perkembangan keterampilan motorik, kemampuan fisik, pengetahuan dan penalaran, penghayatan nilai-nilai (sikap, mental, emosional, spiritual, sosial), serta pembiasaan pola hidup sehat yang bermuara untuk merangsang pertumbuhan dan perkembangan yang seimbang. Di dalam intensifikasi penyelenggaraan pendidikan sebagai suatu proses pembinaan manusia yang berlangsung seumur hidup, peranan Pendidikan Jasmani adalah sangat penting, yakni memberikan kesempatan pada siswa untuk terlibat langsung dalam 
aneka pengalaman belajar melalui aktivitas jasmani yang dilakukan secara sistematis. Pembekalan pengalaman belajar itu diarahkan untuk membina, sekaligus membentuk gaya hidup sehat dan aktif sepanjang hayat. Tidak ada pendidikan yang tidak mempunyai sasaran pedagogis, dan tidak ada pendidikan yang lengkap tanpa adanya pendidikan jasmani, karena gerak sebagai aktivitas jasmani adalah dasar bagi manusia untuk mengenal dunia dan dirinya sendiri yang secara alamiah berkembang searah dengan perkembangan zaman (Anwar, 2005).

Gerak berhubungan dengan kinesiologi. Kinesiologi adalah studi tentang gerakan. Kinesiologi menyatukan bidang anatomi, fisiologi, fisika, dan geometri, yang dihubungkan dengan gerakan manusia (Vanagosi, 2015). Lippert (2006) menyatakan kinesiology utilizes principles of mechanics, musculoskeletal anatomy, and neuromuscular physiology. Kinesiologi adalah kajian saintifik mengenai pergerakan manusia. Sebagai ilmu yang mempelajari gerakan tubuh manusia, kinesiologi menitik beratkan ilmu yang berhubungan dengan gerakan manusia antara lain elemen-elemen anatomi, fisiologi dan mekanika yang mempunyai kaitan dengan pergerakan terutama tulang, otot, sendi, sistem saraf, dan sistem rangka. Kinesiologi merupakan ilmu yang penting bagi penyiapan guru pendidikan jasmani dan ahli dibidang olahraga secara profesional. Melalui kinesiologi analisis gerak yang efesien, efektif dan aman berkaitan dengan analisis tulang dan sendi, sistem otot saraf dari gerakan manusia, dan asas-asas hukum mekanika yang dihubungkan dengan gerakan manusia akan tercipta dengan baik.

Dalam perubahan Kurikulum 2013 perkembangan ilmu gerak tetap sebagai suatu bidang studi akademis yang bersumber dari berbagai perilaku gerak. Perilaku gerak memerlukan adanya koordinasi fungsional antara persyarafan dan otot serta fungsi kognitif, afektif, dan konatif. Perilaku gerak utama yang bersifat umum harus dikuasai oleh setiap manusia, yaitu: berjalan dan memegang benda merupakan jenis keterampilan gerak dasar serta bermain, dan bekerja merupakan keterampilan gerak penunjang. Pengembangan Kurikulum 2013 merupakan bagian dari strategi meningkatkan capaian pendidikan. Orientasi Kurikulum 2013 adalah terjadinya peningkatan dan keseimbangan antara kompetensi sikap (attitude), keterampilan (skill) dan pengetahuan (knowledge). Pengetahuan dan 
perkembangan ilmu gerak harus dimiliki oleh seorang guru pendidikan jasmani. Pengajaran gerak-gerak dasar, gerak keterampilan, serta perbaikan gerak sangat tergantung kepada pengetahuan ilmu gerak.

Perkembangan fisik merupakan hal yang sangat penting bagi anak sekolah dasar (SD). Sebenarnya anggapan bahwa perkembangan fisik akan berkembang secara otomatis dengan bertambahnya usia anak, merupakan anggapan yang keliru. Perkembangan fisik pada anak perlu adanya bantuan dari para pelatih/pendidik di lembaga pendidikan. Hal yang perlu mendapat bantuan bagaimana jenis latihan yang sesuai bagi anak sekolah dasar dan bagaimana kegiatan fisik yang menyenangkan anak. Oleh karena ini kinesiologi olahraga menjadi hal yang sangat penting untuk anak sekolah dasar dan memerlukan pendampingan guru dalam lingkup pendidikan.

Atas dasar latar belakang tersebut maka pengabdian masyarakat ini membahas tentang Sosialisasi Kinesiologi Olahraga Pada Pembelajaran PJOK Anak Sekolah Dasar.

\section{Metode}

Pelaksanaan pengabdian ini terdiri dari kegiatan tersebut sebagai berikut:

a. Penjelasan terkait materi sosialisasi kinesiologi olahraga pada pembelajaran PJOK anak sekolah dasar.

b. Diskusi tanya jawab terkait materi

c. Diskusi tentang kinesiologi olahraga pada pembelajaran PJOK anak sekolah dasar di SDK Maria Fatima Bangkalan.

Adapun jadwal kegiatan dilaksanakan pada:

Bulan : November 2021

Tempat : SDK Maria Fatima Bangkalan

Jumlah peserta : 15 siswa kelas atas

Peran Mitra yang terlibat pada program ini adalah guru dan staf SDN, serta siswa kelas atas SDK Maria Fatima Bangkalan. Lokasi kegiatan adalah di Kecamatan Bangkalan, Kabupaten Bangkalan Jawa Timur. Waktu pelaksanaan kegiatan adalah 
November sampai Desember 2021 (kurun waktu 1 bulan). Adapun durasi kegiatan pengabdian selama 1 bulan yang terbagi dalam beberapa tahap sebagai berikut:

\begin{tabular}{|c|c|c|c|}
\hline NO & Nama Kegiatan & $\begin{array}{l}\text { Urutan } \\
\text { Tahun }\end{array}$ & Pelaksanaan \\
\hline 1 & $\begin{array}{l}\text { Mempersiapkan analisis situasi dengan } \\
\text { berkoordinasi dengan mitra. }\end{array}$ & 2021 & November 2021 \\
\hline 2 & $\begin{array}{l}\text { Melakukan identifikasi masalah yang } \\
\text { ditemukan dengan mitra. }\end{array}$ & 2021 & November 2021 \\
\hline 3 & $\begin{array}{l}\text { Menentukan tujuan kegiatan dengan } \\
\text { memperhatikan perkembangan masyarakat. }\end{array}$ & 2021 & November 2021 \\
\hline 4 & Merencanakan pemecahan masalah & 2021 & November 2020 \\
\hline 5 & $\begin{array}{l}\text { Melakukan pendekatan pada sekolah } \\
\text { sasaran. }\end{array}$ & 2021 & November 2020 \\
\hline 6 & $\begin{array}{l}\text { Melaksanakan kegiatan sosialisasi } \\
\text { kinesiologi olahraga pada pembelajaran } \\
\text { PJOK anak sekolah dasar }\end{array}$ & 2021 & November 2021 \\
\hline 7 & $\begin{array}{l}\text { Menyiapkan laporan kegiatan pengabdian } \\
\text { masyarakat. }\end{array}$ & 2021 & Desember 2021 \\
\hline 8 & $\begin{array}{l}\text { Mengumpulkan dokumentasi kegiatan } \\
\text { sebelumnya dan mempublikasikan hasil } \\
\text { kegiatan. }\end{array}$ & 2021 & Desember 2021 \\
\hline
\end{tabular}

Evaluasi dari program pengabdian ini akan dilaksanakan dengan dua kegiatan sebagai berikut:

Evaluasi dan keberlanjutan program berikutnya akan menjadi perhatian intensif dari mitra yaitu SDK Maria Fatima Bangkalan yang dapat dilakukan melalui program kerja tahunan mereka yang akan direncanakan berikutnya. Pengusul yang merupakan dosen program studi pendidikan olahraga STKIP PGRI.

\section{Hasil dan Diskusi}

Hasil dari kegiatan yang dilaksanakan selama kegiatan berlangsung partisipasi siswa dalam mengikuti pelaksanaan sosialisasi. Karena dalam masa New Normal Sosialisasi dilaksanakan secara luring dan membatasi jumlah siswa dan tetap menerapkan protokol kesehatan. Pada pelaksaan diberikan materi tersebut agar siswa bisa mengikuti. Kemudian 
dilakasanakan tanya jawab dan diskusi.

Materi sosialisasi yaitu terkait kinesiologi dalam PJOK pada siswa sekolah dasar, meliputi penejelasan terkait gerak-gerak dasar, gerak keterampilan, serta perbaikan gerak pada PJOK. Selain itu juga dilakukan praktek singkat pada setiap siswa, kemudian diperbaiki gerak yang benar. Masih ada beberapa anak yang gerakannya masih perlu perbaikan. Sehingga dibetulkan dan dicontohkan gerakan yang benar.

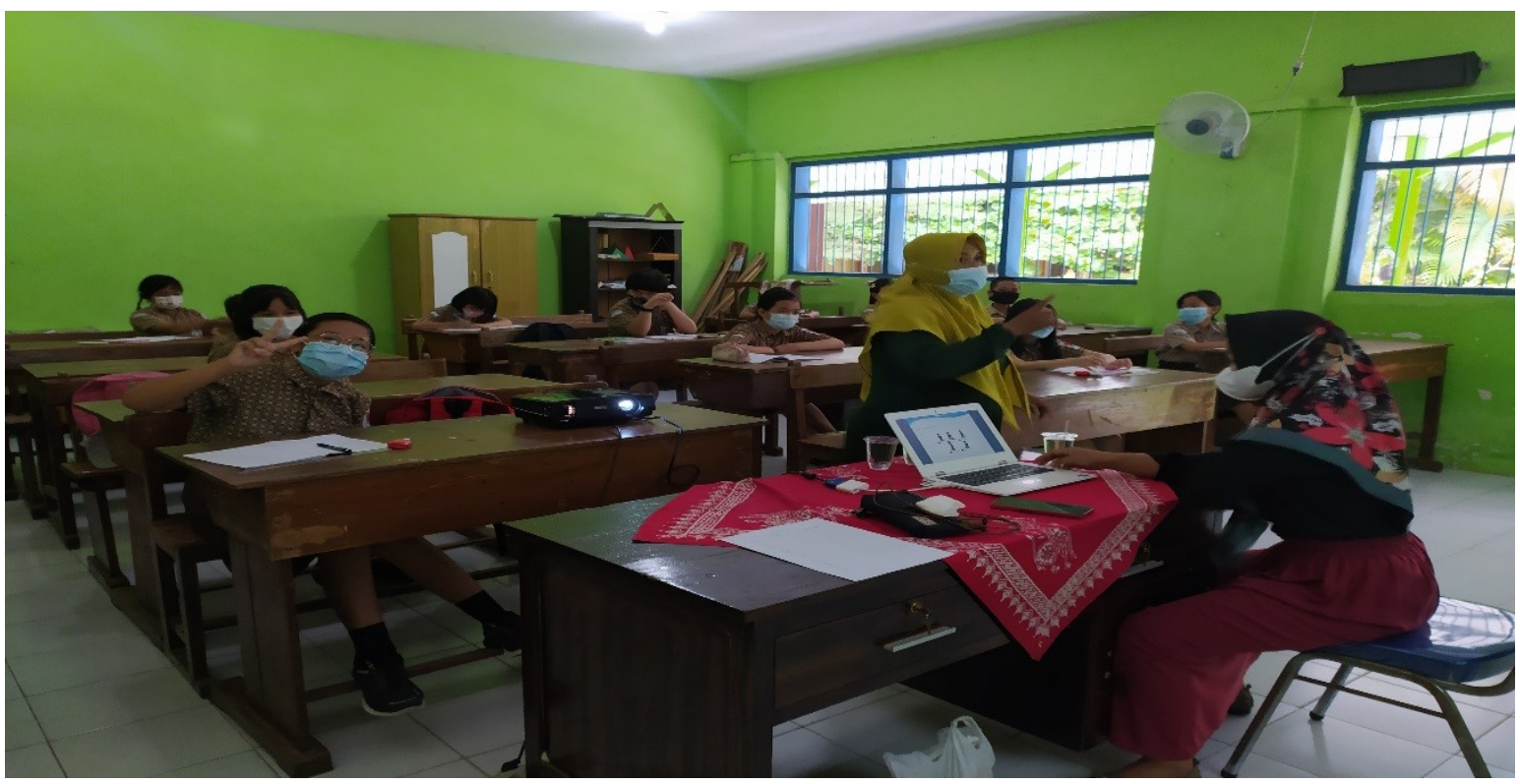

Gambar 1. Berkoordiniasi dengan mitra guru

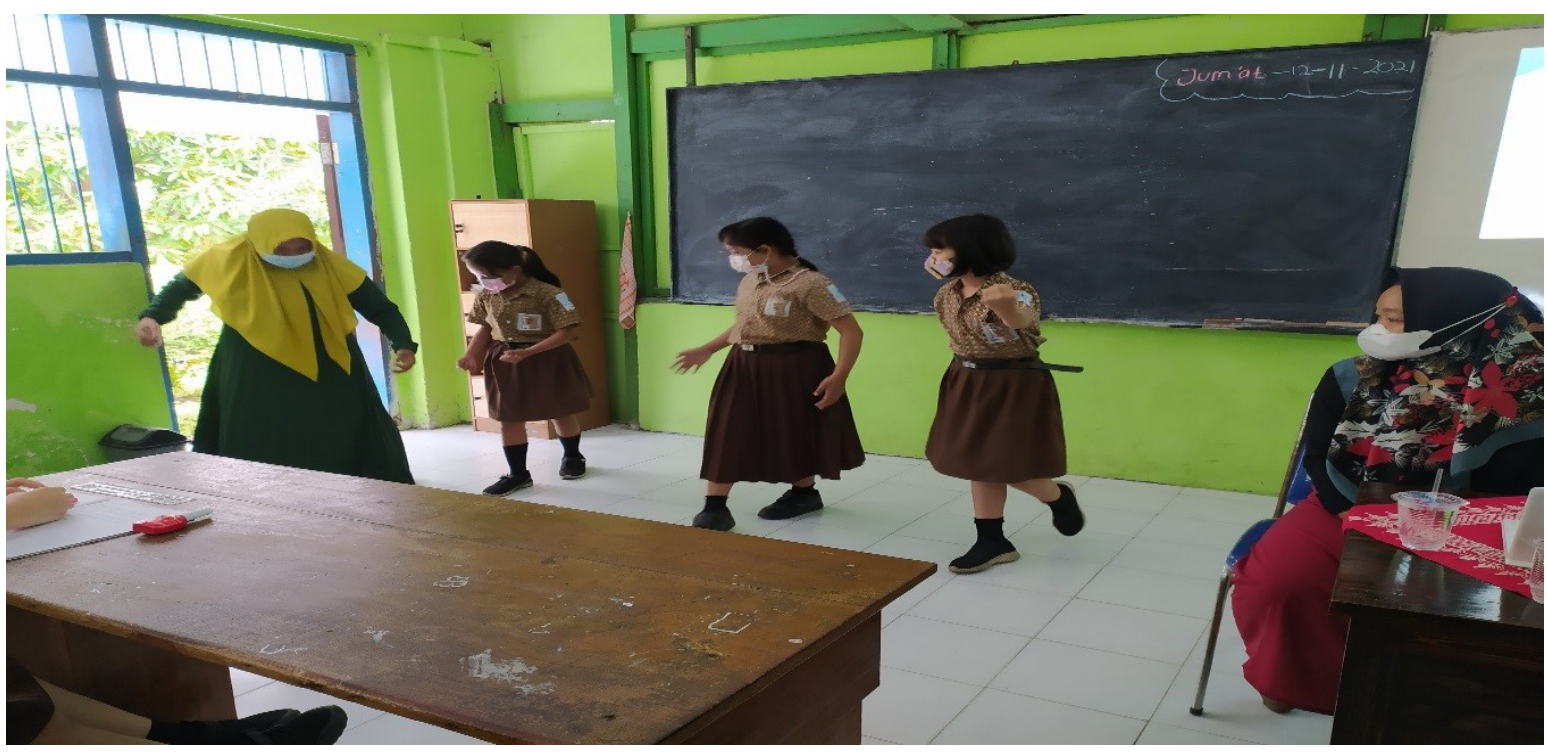

Gambar 2. Mengajarkan kepada anak Sekolah Dasar 
Terkait gerak anak harus memperhatikan karakteristiknya. Karakteristik anak usia sekolah dasar berkaitan dengan aktivitas fisik yaitu umumnya anak senang bermain, senang bergerak, senang bekerja dalam kelompok, dan senang praktik langsung (Abdul Alim, 2009). Oleh karena itu dalam kinesiology PJOK anak sekolah dasar harus disesuaikan dengan karakteristiknya. Pada anak sekolah dasar umumny senang bermain, oleh karena itu gerak dalam PJOK yaitu gerak dalam bentuk permainan. Kemudian karakteristik senang bekerja dalam kelompok maka dalam gerak di PJOK dengan menggunakan metode kelompok. Selain itu anak sekolah dasar juga senang jika praktek langsung, maka dalam praktek gerak PJOK dilaksanakan dengan praktek langsung yang jelas. Karateristik anak sekolah dasar menurut Abdul Alim (2009) sebagai berikut.

1. Anak usia SD senang Bermain Pendidik diharuskan paham dengan perkembangan anak, memberikan aktifitas fisik dengan model bermain. Materi pembelajaran dibuat dalam bentuk games, terutama pada siswa SD kelas bawah (kelas $1 \mathrm{~s} / \mathrm{d}$ 3) yang masih cukup kental dengan zona bermain. Sehingga rancangan model pembelajaran berkonsep bermain yang menyenangkan, namun tetap memperhatikan ketercapaian materi ajar.

2. Anak usia SD senang bergerak Anak usia SD berbeda dengan orang dewasa yang betah duduk berjam-jam, namun anak-anak berbeda bahkan kemungkinan duduk tenang maksimal 30 menit. Pendidik berperan untuk membuat pembelajaran yang senantiasa bergerak dinamis, permainan menarik memberi Erick Burhaein Aktivitas Fisik Olahraga untuk Pertumbuhan dan Perkembangan Siswa SD

3. Anak usia SD senang beraktifitas kelompok Anak usia SD umumnya mengelompok dengan teman sebaya atau se-usianya. Konsep pembelajaran kelas dapat dibuat model tugas kelompok, pendidik memberi materi melalui tugas sederhana untuk diselesaikan bersama. Tugas tersebut dalam bentuk gabungan unsur psikomotor (aktifitas gerak) yang melibatkan unsur kognitif. Misal anak usia SD diberi tugas materi gerak sederhana menjelaskan menembak bola (shooting), maka untuk memperoleh 
jawaban mereka akan mempraktikkan dahulu kemudian memaparkan sesuai kemampuan mereka.

4. Anak usia SD senang praktik langsung. Anak usia sekolah dasar, memiliki karakteristik senang melakukan hal secara model praktikum, bukan teoritik. Berdasarkan ketiga konsep kesenangan sebelumnya ( senang bermain, bergerak, berkelompok) anak usia SD, tentu sangat efektif dikombinasikan dengan praktik langsung. Pendidik memberikan pengalaman belajar anak secara langsung, sehingga pembelajaran model teori klasikal tidak terlalu diperlukan atau diberikan saat evaluasi.

Ilmu gerak (Kinesiologi) merupakan suatu bidang studi yang berkaitan dengan analisa kerangka otot dan pelajaran tentang asas-asas hukum-hukum mekanika yang dihubungkan dengan gerakan manusia. Ilmu gerak dalam pembelajaran di sekolah diberikan pada pelajaran pendidikan jasmani olahraga, dan kesehatan (Penjasorkes). Model pembelajaran kinesiologi pada umumnya dipilih oleh guru-guru penjas. Meskipun banyak sekolah telah memasukkan satu atau dua unit konsep dalam kurikulum, khususnya dipadukan dengan sehat bugar jasmani, sedikit sekali sekolah yang hanya memakai model kinesiologi secara tunggal, tetapi tidak ada salahnya model inipun sudah mulai diperkenalkan di sekolah dasar dengan persoalan prinsip gerak yang disederhanakan (Vanagosi, 2015).

Dalam memberikan pembelajaran penjasorkes guru pendidikan jasmani harus memiliki pengetahuan tentang ilmu gerak, dengan memahami dasar-dasar gerakan, guru pendidikan jasmani dapat memperbaiki gerakan yang pada dasarnya memerlukan latihan sehingga gerakan-gerakan tersebut menjadi terlatih yang kualitasnya lebih tinggi serta dapat memberikan hasil yang lebih besar bagi peserta didiknya. Menurut Kretchmar (1994) Penjasorkes memberikan kontribusi yang baik bagi kehidupan manusia, kontribusinya terhadap organ biologik, psikomotorik afektif, dan kognitif bagi para pelakunya. Selain itu, penjasorkes mampu mengembangkan pola hidup yang sehat dan aman, serta memiliki peran penting dalam mempengaruhi pola aktivitas dan kesehatan individu maupun masyarakat (Whitehead, 2001). Sejalan dengan itu, maka fungsi penjasorkes di sekolah adalah untuk meningkatkan aspek (1) organik, (2) neuromuskuler, (3) perseptual, (4) kognitif, (5) sosial, dan (6) emosional siswa (Depdiknas, 2003). Pendidikan jasmani olahraga, dan kesehatan 
merupakan bagian integral dari pendidikan secara keseluruhan, yang bertujuan untuk mengembangkan aspek kebugaran jasmani, keterampilan gerak, keterampilan berfikir kritis, keterampilan sosial, penalaran, stabilitas emosional, tindakan moral, aspek pola hidup sehat dan pengenalan lingkungan bersih melalui aktivitas jasmani, olahraga dan kesehatan yang direncanakan secara sistematis dalam rangka mencapai tujuan pendidikan nasional.

Analisis gerak pada manusia dapat dikaji lebih dalam melalui ilmu gerak yaitu Kinesiologi. Kinesiologi adalah ilmu yang mempelajari gerak atau the science human movement yang diaplikasikan dan menjelaskan tentang gerak tubuh manusia kemudian ilmu ini dapat diaplikasikan terhadap prinsip-prinsip mekanik dalam gerak manusia yang disebut biomekanika kinesiologi, sedangkan aplikasi anatomi dalam gerak manusia disebut anatomi kinesiologi. Tujuan mempelajari kinesiologi diharapkan para siswa memiliki kemampuan untuk menganalisis gerak yang efisien, efektif dan terhindar dari cidera, dengan pendekatan aplikasi fungsi tulang dan persendian, otot, skelet, sistem saraf serta mekanika. Oleh karean itu kinesiologi dalam pembelajaran PJOK sangat diperlukan dan harus dipahami oleh anak didik. Pada pengabdian terkait tahap awal yaitu mempersiapkan analisis situasi dengan berkoordinasi dengan mitra. Maka peneliti ke sekolah dan melakukan koordinasi dengan guru PJOK terkait kinesiologi pada PJOK. Pada identifikasi masalah yang ditemukan dengan mitra bahwa masih banyak gerakan siswa dalam PJOK yang memerlukan perbaikan. Oleh karena itu diperlukan sosialisasi terkait kinesiologi dalam pembeljaran PJOK, sebagai upaya untuk memberikan pemahaman terkait gerak yang benar dan memperbaiki gerakan yang kurang tepat dalam pembelajaran PJOK. Selain itu juga dijelaskan terkait gerak yang efisien dalam pembelajaran PJOK, gerak yang efektif dan terhindar dari cidera. Tidak lupa pula dijelaskan secara singkat terkait fungsi tulang dan persendian, otot, skelet, sistem saraf serta mekanika, karena yang mendukung dalam bergerak.

\section{Kesimpulan}

Dari kegiatan pengabdian kepada masyarakat ini didapatkan kesimpulan sebagai berikut:

1) Pengabdian ini berhasil, membuat siswa lebih paham tentang kinesiologi 
JURNAL ASTA

Abdi Masyarakat Kita

Vol. 02 No. 01, Januari 2022

olahraga dalam pembelajaran PJOK anak sekolah dasar

2) Melalui kegiatan sosialisasi ini maka guru harus memberikan pemahaman lebih dalam terkait kinesiologi pada anak sekolah dasar dan guru selalu memberikan pendampingan terhadap gerak anak sekolah dasar.

3) Gerak dalam PJOK harus memperhatikan karakteristik anak sekolah dasar

4) Siswa memahami gerak yang efisien, gerak yang efektif dan terhindar dari cidera dalam pembelajaran PJOK.

\section{Ucapan Terimakasih}

Ucapan terimakasih disampaikan kepada guru, staf, dan siswa di SDK Maria Fatima Bangkalan. Selain itu juga tidak lupa ucapan terimakasih untuk STKIP PGRI Bangkalan yang telah memberikan ijin tugas untuk melaksanakan pengabdian masyarakat.

\section{Daftar Pustaka}

Abdul Alim. (2009). Permainan Mini Tenis untuk pembelajaran pendidikan Erick Burhaein Aktivitas Fisik Olahraga untuk Pertumbuhan dan Perkembangan Siswa SD. Jasmani Olahraga dan Kesehatan Siswa di Sekolah Dasar. JPJI, 6(2).

Anwar, M.H. (2005). Pendidikan Jasmani Sekolah Dasar Sebagai Wahana Kompensasi Gerak Anak. Jurnal Pendidikan Jasmani Indonesia, 3(1): 45-53.

Depdiknas. (2003). Kurikulum 2004: Standar Kompetensi Mata Pelajaran Pendidikan Jasmani SMP dan MTS. Jakarta: departemen Pendidikan Nasional.

Lippert, Lynn S. (2006). Clinical Kinesiology and Anatomy4thed. Philadelphia: F. A. Davis Company.

Kretchmar, R. Scott. (1994). Practical Philosophy of Sport. Champaign, IL: Human Kinetics

Vanagosi, K.D. (2015). Analisis Kinesiologi Teknik Cabang Olahraga Panahan. Jurnal Pendidikan Kesehatan Rekreasi, 1(1): 70-75.

Whitehead, M. (2001). The Concepts of Physical Literacy. The British Journal of Teaching Physical Education 